\title{
A review of possibilities for using animal tracking devices to mitigate stock theft in smallholder livestock farming systems in rural South Africa
}

Zantsi, S. ${ }^{1}$ and Nkunjana, T. ${ }^{2}$

Corresponding Author: S. Zantsi. Email: siphezantsi@ yahoo.com

\section{ABSTRACT}

Stock theft is among the major challenges faced by livestock farmers in South Africa. It has severe consequences especially for smallholder farmers, who collectively own a large share of the South African livestock herds but individually keep small herds. In recent years, technological improvements and innovations have made it possible to track livestock movements by using GPS animal tracking devices. Low-cost GPS has been developed and used elsewhere and in the local commercial sector. Given the well-known role of extension, i.e. information and technology dissemination, the possibility that smallholders adopt GPS animal tracking devices should be evaluated. However, very few studies have made a case for using this technology in curbing stock theft among smallholder farmers. This review therefore addresses the likelihood that smallholder livestock farmers in South Africa adopt GPS animal tracking devices to mitigate the impact of stock theft. Using a semi-systematic and a snowball literature review approach, we consulted and reviewed the relevant literature and official statistics relating to stock theft and smallholder livestock farming. Results from the reviewed literature suggest that the likelihood of GPS animal tracking device adoption by smallholders will depend on a) the awareness about the devices and how they work, b) the acuteness of stock theft for a farmer and how livestock contributes the farmer's livelihood, and c) the income level, access to mobile phones and risk behaviour of farmers. Our literature findings identify areas for future research and may help agricultural extension personnel with future research topics.

Keywords: GPS; Agricultural extension; integrative review; stock theft, South Africa

\section{INTRODUCTION}

Among the numerous challenges in smallholder farming systems, stock theft appears to be one major problem (Ntsebeza, 2002; Maluleke, Obioha \& Mofokeng, 2014; Clack, 2015, 2018; Bahta, Jordaan \& Muyambo, 2016; Maluleke \& Mofokeng, 2016; Maluleke, Mokwena, \& Motsepa, 2016; Lombard, Van Niekerk \& Maré, 2017; Geldenhuys, 2020). For smallholder farmers, who mostly keep small herds, the loss of one livestock unit can have a severe impact on the livelihood of the owner (Clack, 2018). Numerous researchers have recommended methods to curb stock theft, for example branding, tattooing and frequently counting animals

\footnotetext{
${ }^{1}$ PhD student, Department of Agricultural Economics, Stellenbosch University, Private Bag X1, Matieland, 7602, Stellenbosch, South Africa; Agroscope, Socio-economic group, Tänikon 1, Ettenhausen 8356, Switzerland.Tel +41 584818373 E-mail: siphezantsi.yahoo.com: https://orcid.org/0000-0001-9787-3913

${ }^{2}$ Economist, agro-food chain unit, National Agricultural Marketing Council, 536 Francis Baard Street, Arcadia, Pretoria, 0002, South Africa, E-mail:thabile@namc.co.za
} 
(Lombard et al, 2017). Zwane, Marle-Köster, Greyling and Mapholil (2013) and Maluleke and Mofokeng (2016) suggested the use of forensic DNA technology to mitigate stock theft. However, stock theft remains a major problem in rural South Africa.

In line with technological advances and innovations, animal tracking devices have been recommended as one possible solution to reduce stock theft (Nel, 2016). The GPS animal tracking devices come in various forms, with the most popular form being a neck belt tied to the animal, whose owner can track the animal movement on a smartphone or computer (Schieltz, Okanga, Allan \& Rubenstein, 2017). Nkwari, Rimer and Paul (2014) successfully modelled the typical behaviour of a cow to determine anomalies in behaviour that could indicate the presence of unknown persons (thieves). The combination of these innovations could be useful in curbing stock theft.

In addition, a GPS animal tracking device programmed with typical animal behaviour not only seems to offer one possible solution to stock theft but also could help livestock farmers save time in finding their livestock animals when they wander in shared grazing lands (Zantsi \& Bester, 2019a). However, it remains questionable whether this device is economically viable to be adopted in the resource-poor smallholder farming systems in South Africa. This review therefore seeks to explore, reveal and discuss possibilities of using such device in smallholder livestock farming systems in rural South Africa.

\section{METHODOLOGY}

Literature reviews have emerged as one form of research for answering various research questions. Among many useful cases for which literature reviews can be used, Snyder (2019) suggested that literature reviews are also useful when the researcher aims to provide an overview of a certain issue or research problem. The other useful case is when a researcher wants to evaluate the state of knowledge on a particular topic. The latter, according to Snyder (2019), can be useful to create research agendas, identify gaps in research, or simply discuss a particular matter.

This article follows an integrative literature review approach to address the research problem at hand. An integrative literature review is a combination of review methods (Snyder, 2019). Our study combines semi-systematic and snowball literature reviews (similar to the approach used by Fielke, Taylor \& Jakku, 2020). The purpose of this review is to stimulate and probe a discussion from the existing data and literature on the possibility of smallholder farmers adopting and using animal tracking devices. The General Household Survey of 2016 from Statistics South Africa and the national statistics from the South African Police Service (SAPS) are the major sources of data used in this paper. These were used to firstly gain insight on the composition and constituents of smallholder farming systems in the country. Secondly, the SAPS statistics on livestock theft was used to determine the magnitude and the degree to which stock theft affects livestock keeping among smallholders. Of course, other relevant sources of literature were used to balance the discussion about the research problem at hand. 
Relevant in this respect were studies that discuss or describe smallholder farming in South Africa and studies that describe or discuss stock theft. The criteria for including studies were based on these aspects of relevance and assessed by first reading the abstract of each reviewed study. Studies that met the predefined criteria were read in detail and synthesised. Large databases for scientific literature, such as Sabinet African Journals and Scopus, were used and accessed from the Stellenbosch University's electronic databases. However, this study only used literature that is written in English language. Other sources written for example in Afrikaans were not included.

\section{RESULTS OF THE INTEGRATIVE LITERATURE SYNTHESIS}

To understand the possibility and likelihood of smallholders' adoption of GPS animal tracking devices, it is important to first understand the context of smallholder farming and livestock farming in general. Second, it is necessary to identify the various types of smallholders and their salient characteristics to allow an informed discussion on which types of smallholders would be likely to use the devices and what important attributes would inform their decisions. Thus, smallholder socio-economic information such as incomes and education will be analysed.

\subsection{Profile of livestock farmers in South Africa}

Livestock farming is an important and the largest agricultural subsector contributing more than $40 \%$ of the national agricultural production value. Like the rest of the South African agricultural sector, it comprises small-scale and large-scale farmers. Livestock production is spread across South Africa, but the production concentration varies from province to province. Latest data show that livestock numbers decreased noticeably between August 2018 and May 2019. The numbers of cattle, sheep, pigs and goats were estimated to have decreased by $1.41 \%, 1.27 \%$, $3.79 \%$ and $2.35 \%$, respectively (Department of Agriculture, Forestry and Fisheries [DAFF], 2019). In terms of production, the Eastern Cape had the highest percentage of cattle, sheep and goats followed by KwaZulu-Natal and Free State for the same period (DAFF, 2020).

The official 2017 census released by Statistics South Africa in March 2020 revealed that there are about 40122 commercial farms in South Africa with livestock farms constituting the largest portion (13 639; 34\%), followed by mixed farms (12 458; 31\%) and field crop farms (8 559; 21\%) (Statistics South Africa, 2020). Table 1 presents animal numbers by animal category and by province. The presented data in Table 1 show that the Eastern Cape has the largest livestock portion $(28 \%$ ) of all provinces, followed by the Northern Cape and Free State (both $16 \%$ ). The country has well-established meat producing industries together with value added activities such as slaughtering, processing, etc. For this reason, it is expected that commercial farming would be a major player in the industry; nonetheless, there are also subsistence and smallholder farmers equally important for the industry. 
Table 1 Livestock numbers per category and province

\begin{tabular}{|c|c|c|c|c|c|c|c|c|c|c|}
\hline \multicolumn{11}{|c|}{ Number of cattle per province in May 2019} \\
\hline S.A & WC & NC & FS & EC & KZN & MP & $\mathbf{L}$ & $\mathbf{G}$ & NW & RSA \\
\hline$\%$ & 4 & 3 & 17 & 24 & 19 & 10 & 7 & 2 & 12 & 100 \\
\hline $\begin{array}{l}\text { Num } \\
\text { ber }\end{array}$ & $\begin{array}{l}498,00 \\
0\end{array}$ & $\begin{array}{l}442,00 \\
0\end{array}$ & $\begin{array}{l}2,111, \\
000\end{array}$ & $\begin{array}{l}3,104 \\
000\end{array}$ & $\begin{array}{l}2,465 \\
000\end{array}$ & $\begin{array}{l}1,261 \\
000\end{array}$ & $\begin{array}{l}910,0 \\
00\end{array}$ & $\begin{array}{l}243,0 \\
00\end{array}$ & $\begin{array}{l}1,575 \\
000\end{array}$ & $\begin{array}{l}12,700, \\
000\end{array}$ \\
\hline \multicolumn{11}{|c|}{ Number of sheep per province in May 2019} \\
\hline$\%$ & 12 & 24 & 21 & 29 & 3 & 7 & 1 & 0 & 3 & 100 \\
\hline $\begin{array}{l}\text { Num } \\
\text { ber }\end{array}$ & $\begin{array}{l}2,663, \\
000\end{array}$ & $\begin{array}{l}5,344, \\
000\end{array}$ & $\begin{array}{l}4,573, \\
000\end{array}$ & $\begin{array}{l}6,540, \\
000\end{array}$ & $\begin{array}{l}657,00 \\
0\end{array}$ & $\begin{array}{l}1,567 \\
000\end{array}$ & $\begin{array}{l}204,0 \\
00\end{array}$ & $\begin{array}{l}87,00 \\
0\end{array}$ & $\begin{array}{l}608,00 \\
0\end{array}$ & $\begin{array}{l}22,213, \\
000\end{array}$ \\
\hline \multicolumn{11}{|c|}{ Number of goats per province in May 2019} \\
\hline$\%$ & 4 & 9 & 4 & 38 & 13 & 2 & 17 & 0 & 13 & 100 \\
\hline $\begin{array}{l}\text { Num } \\
\text { ber }\end{array}$ & $\begin{array}{l}207,00 \\
0\end{array}$ & $\begin{array}{l}470,00 \\
0\end{array}$ & $\begin{array}{l}216,00 \\
0\end{array}$ & $\begin{array}{l}2,019, \\
000\end{array}$ & $\begin{array}{l}682,00 \\
0\end{array}$ & 80,000 & $\begin{array}{l}909,0 \\
00\end{array}$ & $\begin{array}{l}24,00 \\
0\end{array}$ & $\begin{array}{l}669,00 \\
0\end{array}$ & $\begin{array}{l}5,276,0 \\
00\end{array}$ \\
\hline \multicolumn{11}{|c|}{ Total number of livestock (cattle, sheep, goats) in May 2019} \\
\hline$\%$ & $\begin{array}{l}33680 \\
00\end{array}$ & $\begin{array}{l}62560 \\
00\end{array}$ & $\begin{array}{l}69000 \\
00\end{array}$ & $\begin{array}{l}11663 \\
000\end{array}$ & $\begin{array}{l}38040 \\
00\end{array}$ & $\begin{array}{l}29080 \\
00\end{array}$ & \begin{tabular}{|l|}
2023 \\
000
\end{tabular} & \begin{tabular}{|l|}
3540 \\
00
\end{tabular} & $\begin{array}{l}28520 \\
00\end{array}$ & $\begin{array}{l}401890 \\
00\end{array}$ \\
\hline $\begin{array}{l}\text { Num } \\
\text { ber }\end{array}$ & 8 & 16 & 17 & 29 & 9 & 7 & 5 & 1 & 7 & 100 \\
\hline
\end{tabular}

Source: DAFF (2017). WC $=$ Western Cape, NC = Northern Cape, FS = Free State, EC = Eastern Cape, KZN = KwaZulu-Natal, MP = Mpumalanga, L = Limpopo, G = Gauteng, NW = North West, RSA = Republic of South Africa.

\subsection{Profile of smallholder livestock farming systems}

Compared with commercial livestock production, small-scale livestock production in South Africa appears large when gauged by farm numbers, but it is small when gauged by sale of produced animals. However, its contribution to livelihoods is of great importance. According to the 2016 General Household Survey, there are about 2.3 million smallholder agricultural households in South Africa (Statistics South Africa, 2016). Other sources (e.g. Cousins, 2015; Aliber, 2019) that disaggregate agricultural households into different smallholder categories show different compositions of agricultural households, but there is no agreement on their numbers (Liebenberg, 2015; Zantsi, Greyling \& Vink, 2019). A majority of agricultural household heads are black Africans, between the ages of 45 and 55, and a majority of this mean are men (Statistics South Africa, 2016). According to other sources, women and the elderly constitute the greater share of smallholder farmers (Aliber \& Hart, 2009; Pienaar, 2013; 
Raidimi, 2014). Furthermore, most household heads have at least a primary education (see Table 2 for more details).

Of the 2.3 million smallholder households in the country, $27.9 \%$ are in the Eastern Cape, $24.1 \%$ in Limpopo and $18.6 \%$ in KwaZulu-Natal, followed by $18.2 \%$ in Mpumalanga, $16.6 \%$ in Free State and $13.8 \%$ in the Northern Cape; only $3.6 \%$ and $4.9 \%$ are in the Western Cape and Gauteng, respectively (Statistics South Africa, 2016). Furthermore, $42 \%$ of the agricultural households in South Africa farm mostly with animals (see Figure 1). This farming situation somewhat resembles the land distribution in South Africa, where over $60 \%$ of the land is extensive grazing land (DAFF, 2017). The herd size is small for large livestock species (cattle), with $70 \%$ of cattle farmers owning only between one and ten animals, $27 \%$ owning between 10 and 100 animals and 3\% owning more than 100 animals. By comparison, herd sizes are larger for smaller livestock species. Regarding sheep for example, $47 \%$ of households own between 11 and 100 animals and $9.2 \%$ own more than 100 animals.

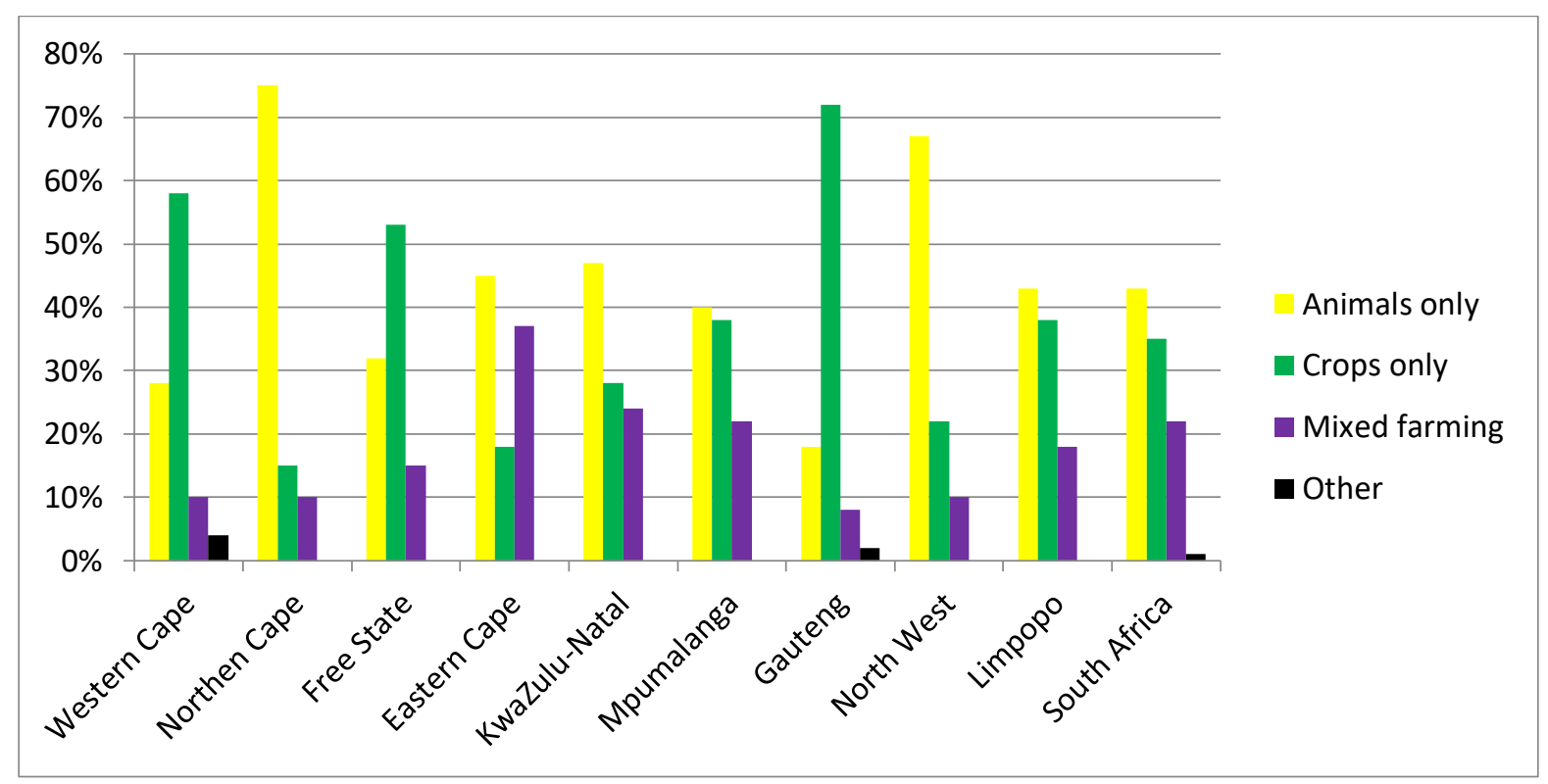

Figure 1 Types of farming activities practiced by agricultural households

Source: Statistics South Africa (2016)

As shown in Figure 2, a large percentage of agricultural households farm mainly to attain a main and an extra source of food (44\% and 38\%, respectively). Similar findings were reported by Aliber and Hart (2009) and Vink and van Rooyen (2009) based on previous national surveys (General Household Survey; Income and Expenditure Survey). Judging from the frame of the answers and the questions in the 2016 General Household Survey (Statistics South Africa, 2016), this large percentage of subsistence farmers might be mostly crop and poultry farming households. Furthermore, very few households farm for attaining a main and an extra income source, and these might arguably be livestock farming households because livestock requires time to yield benefits except for livestock products such as milk. In addition, the depicted situation (Figure 2) entails that very few farmers solely depend on agriculture for a living, but most agricultural households have a diverse portfolio of income sources. 


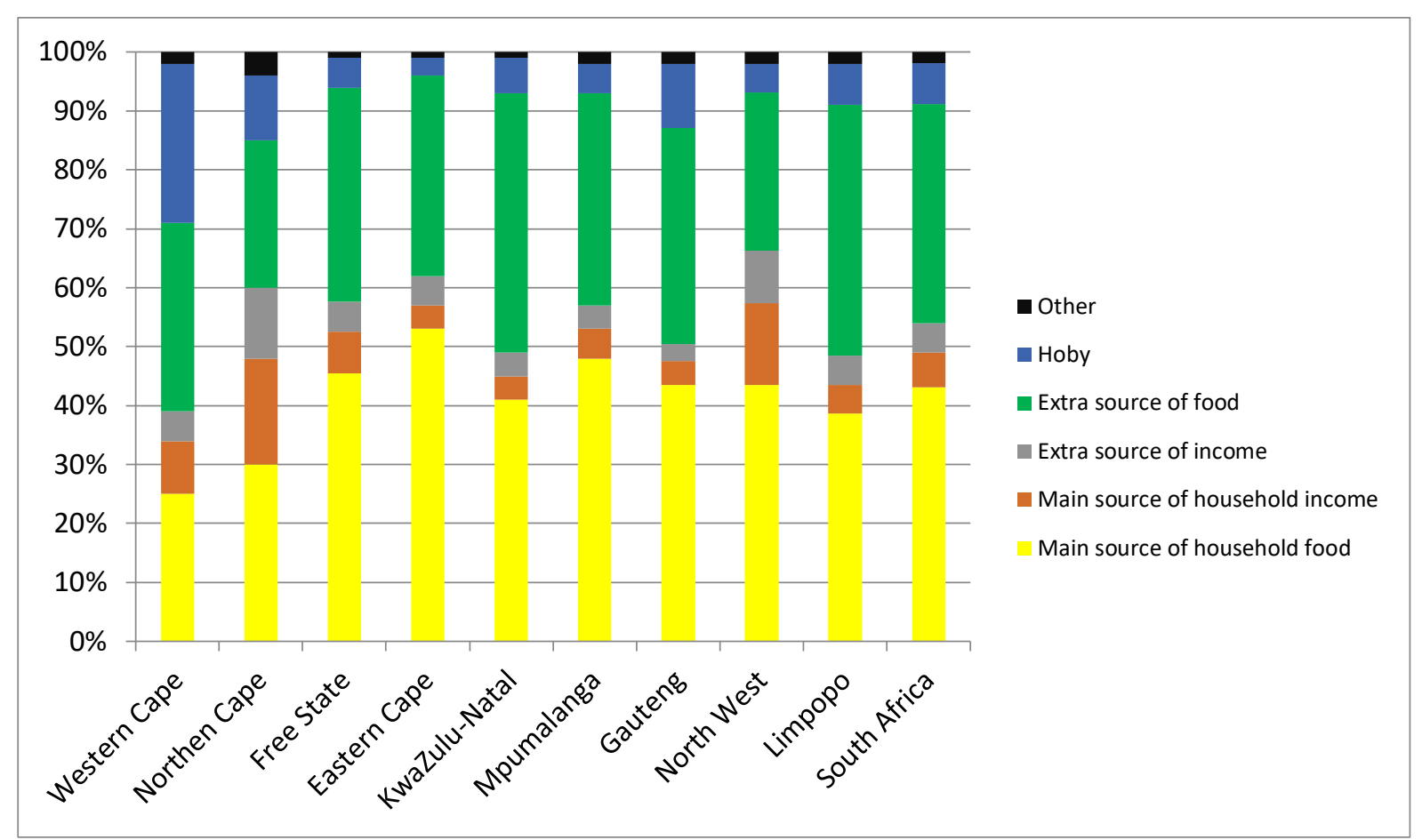

Figure 2 Agricultural households' reasons for farming

Source: Statistics South Africa (2016)

Due to the historical background in South Africa, most of the agricultural households are located in the former homelands (Kirsten \& van Zyl, 1998; Pienaar \& von Fintel, 2014; Okunlola, Ngubane, Cousins \& du Toit, 2016). The 2016 General Household Survey shows that over $60 \%$ of the households are located in three provinces, with $24.9 \%$ in KwaZulu-Natal, 20.7\% in the Eastern Cape and 16.3\% in Limpopo (Statistics South Africa, 2016). Few urban households engage in farming especially livestock, and most urban households farm in their back yards (Conradie, 2013).

\subsubsection{Socio-economics}

In terms of general socio-economics, a majority of smallholder farmers are between the age ranges 30-35 and 65-69, mostly males with primary and secondary education (Statistics South Africa, 2016). Household head education levels according to the 2016 General Household Survey (Statistics South Africa, 2016) are shown in Table 2, showing that most agricultural household heads have education levels between Grade 1 and Grade 11. These socio-economic features may differ between smallholder typologies depending on farming objectives and the intensity and scale of production (Pienaar, 2013). These features provide an important perspective to the adoption of technology. For example, compared with younger farmers, older farmers are known to be more risk averse and more reluctant to adopt new technologies (Van Niekerk, Mahlobogoane \& Tirivanhu, 2015). Furthermore, compared with less educated farmers, educated farmers are perceived to be better in searching for information on appropriate technologies and to better assimilate it in addressing production constraints (Baiyegunhi, Majokweni \& Ferrer, 2019). 
Vol. 49 No. 1, 2021: 162-182

http://dx.doi.org/10.17159/2413-3221/2021/v49n1a10784

Table 2 Education level of household heads in South Africa by province in 2016

\begin{tabular}{|c|c|c|c|c|c|c|c|c|c|c|c|}
\hline \multirow[t]{2}{*}{ Province } & \multicolumn{2}{|c|}{ No schooling } & \multirow{2}{*}{$\begin{array}{l}\text { Grade } 1 \\
11 / \text { Std } 9 \\
2011\end{array}$} & \multirow{2}{*}{$\begin{array}{l}\text { to Grade } \\
2016 \\
\end{array}$} & \multicolumn{2}{|c|}{ Grade 12/Std 10} & \multicolumn{2}{|c|}{ Completed tertiary } & \multicolumn{2}{|l|}{ Other } & \multirow{2}{*}{$\begin{array}{ll}\begin{array}{l}\text { Do } \\
\text { knot }\end{array} & \text { now } \\
2016 & \end{array}$} \\
\hline & 2011 & 2016 & & & 2011 & 2016 & 2011 & 2016 & 2011 & 2016 & \\
\hline Western Cape & 4542 & 2460 & 44858 & 27103 & 18476 & 15590 & 16162 & 21694 & 533 & 705 & 1600 \\
\hline Eastern Cape & 130547 & 84334 & 388383 & 322672 & 45964 & 51941 & 30774 & 31041 & 904 & 1432 & 3148 \\
\hline $\begin{array}{l}\text { Northern } \\
\text { Cape }\end{array}$ & 11013 & 8137 & 32589 & 26953 & 7479 & 7958 & 3927 & 4256 & 138 & 413 & 1070 \\
\hline Free State & 25868 & 16507 & 129508 & 97594 & 32616 & 28621 & 12857 & 11681 & 435 & 410 & 2696 \\
\hline $\begin{array}{l}\text { KwaZulu- } \\
\text { Natal }\end{array}$ & 194458 & 120439 & 398910 & 293304 & 87644 & 81386 & 34860 & 34602 & 1132 & 1616 & 4368 \\
\hline North West & 46583 & 27379 & 126955 & 98555 & 27799 & 26012 & 12321 & 10842 & 388 & 724 & 4240 \\
\hline Gauteng & 20398 & 17898 & 143703 & 118377 & 66263 & 56083 & 47322 & 42217 & 1421 & 783 & 7222 \\
\hline Mpumalanga & 83028 & 57714 & 129193 & 108663 & 36422 & 38078 & 14268 & 13854 & 476 & 874 & 6034 \\
\hline Limpopo & 142904 & 91361 & 235885 & 197136 & 57193 & 61725 & 31665 & 28539 & 843 & 1629 & 5985 \\
\hline South Africa & 659344 & 426229 & 1629995 & 1290357 & 379860 & 367394 & 204160 & 198727 & 6276 & 8585 & 36363 \\
\hline
\end{tabular}

Source: Statistics South Africa (2016) 
Regarding farm household income, numerous studies have reported that small-scale farmers depend much on non-farm income; however, this dependency depends much on the orientation of the farm households. For example, in a more generic approach that captures small-scale farming households, Pienaar and von Fintel (2014) reported that small-scale farming households depend on social grants. In a more specific analysis of subsistence-oriented smallscale farming households, Zantsi and Bester (2019b) reported similar findings that small-scale farming households depend on combining social grants and farming, whereby farming contributes a very small portion to the total household income.

Regarding farm income, Zantsi and Mack (2020) reported that commercially oriented smallscale farming households (which represent the group of emerging farmers) earn an average of R80 703 per year, i.e. R6 725 per month. However, there is a wide range of farm income (from less than R5000 to more than R80000 per year) among the commercially oriented smallholders (Figure 3).

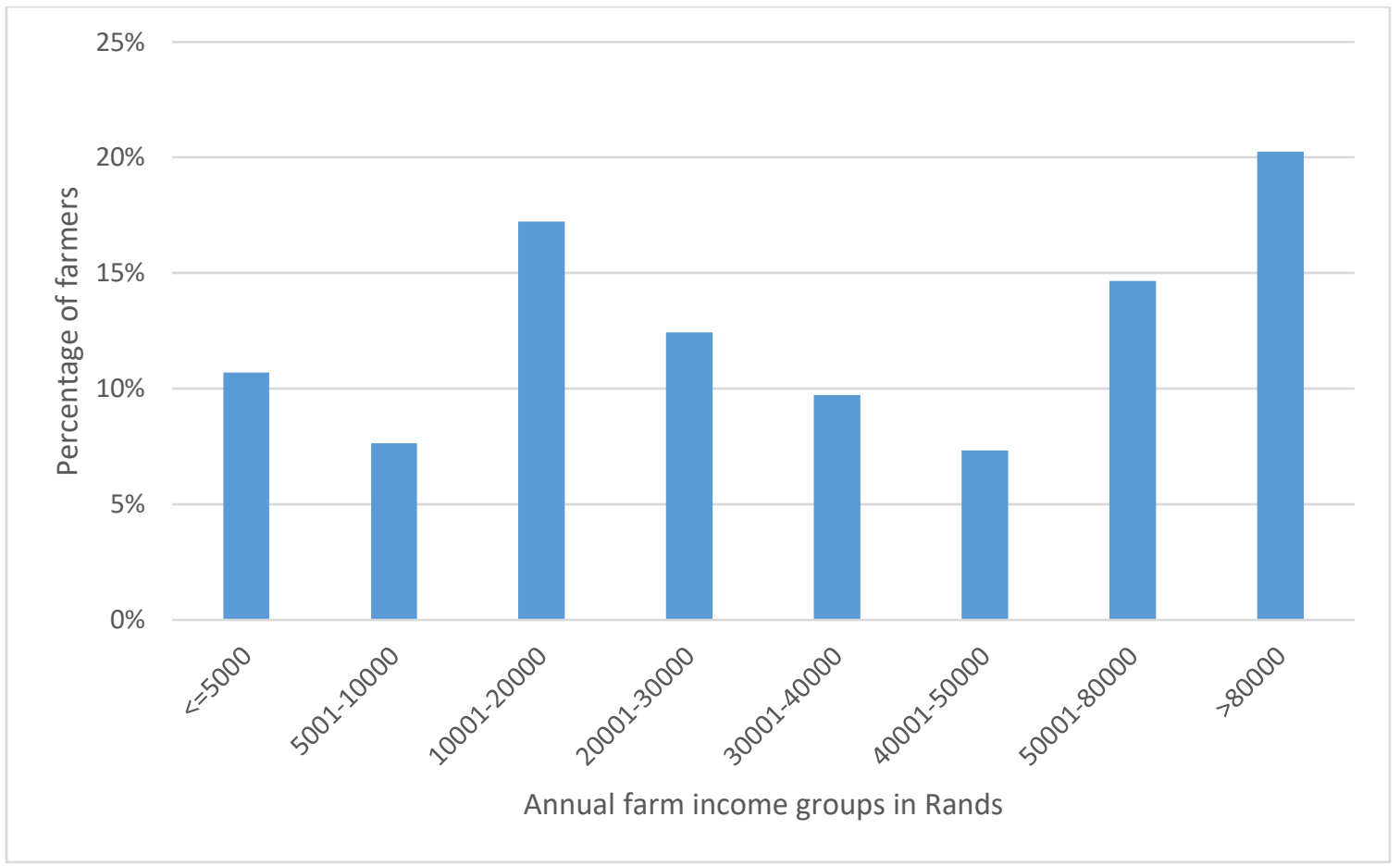

Figure 3 Distribution of annual farm income of emerging farmers

Source: Zantsi and Mack (2020)

\subsubsection{Types of smallholders}

The South African smallholder farming system is quite complex in the sense that it is heterogeneous (Okunlola et al, 2016). Although there are contested definitions and criteria for categorising smallholders (Zantsi et al, 2019), this sector can be categorised into two broad groups, namely communal or subsistence farmers and emerging farmers (commercially oriented smallholders). 
The subsistence or communal farming system comprises the largest group of smallholders, estimated to include more than two million households (Vink \& van Rooyen, 2009; Statistics South Africa, 2016). In the communal farming system, livestock plays a multifunctional role as source of milk, producer of manure to fertilise crop fields, part of cultural purposes (e.g. in ceremonies), provider of draft power, and as a form of capital that one could sell in difficult times (Kunene-Ngubane, Chimonyo \& Kolanisi, 2018). Communal farmers sell very little of their produce and keep small herds (Scholtz \& Bester, 2010; Mthi, Skenjana \& Fayemi, 2017). The group of emerging farmers is estimated to include between 140000 and 160000 households (i.e. it is much smaller than the subsistence group). It is made up of smallholders who farm primarily for the market, and hence their production methods tend to be more intensive than those used by subsistence and semi-subsistence farmers (Pienaar, 2013). The greater portion of the livestock reaches the market, and the off-take for cattle is about $25 \%$ (Scholtz \& Bester, 2010). Gwiriri, Bennett, Mapiye and Burbi (2019) stated that emerging farmers own about $40 \%$ of the national cattle herd. Furthermore, this group makes use of hired labour or non-family labour (Zantsi \& Mack, 2019).

\subsubsection{Challenges: management of stock}

There are numerous challenges for smallholder agriculture in South Africa. For example, communal livestock farmers have limited access to grazing land, which in addition is not fenced (Vetter, 2013). Thus, livestock can wander around, even reaching the national roads and causing accidents. This problem is exacerbated by the shortage of labour, because most of the active population is in cities in search for greener pastures (Daniels, Partridge, Kekana \& Musundwa, 2013). The remaining children attend school regularly, and the active young population is reluctant to participate in agricultural activities (Hull, 2014). This situation forces smallholder households to hire livestock herders, thus further increasing the production costs (Zantsi \& Mack, 2019).

\subsection{Stock theft in South Africa}

Stock theft is one of the important economic crimes affecting the livestock sector in South Africa - for the 2018/2019 financial year, R1.24 billion have been (Geldenhuys, 2020). Lombard et al (2017) estimated that in the Eastern Cape, direct and indirect livestock theft losses amounted to R196 million in 2014. Of this figure, the direct cost of livestock theft was estimated to be R118 million, whereas the indirect cost was calculated to be an additional R77 million (Lombard et al, 2017). Note that these figures are underestimated because more than $70 \%$ of theft cases remain unreported (Clack, 2018), and this theft rate undermines the contribution of the livestock sector to both the national and the household economy (KuneneNgubane et al, 2018; Geldenhuys, 2020). The magnitude and distribution of stock theft are summarised in Figure 4. It shows that cases of reported stock theft are not homogeneous across provinces and that sheep are the most stolen livestock species. 


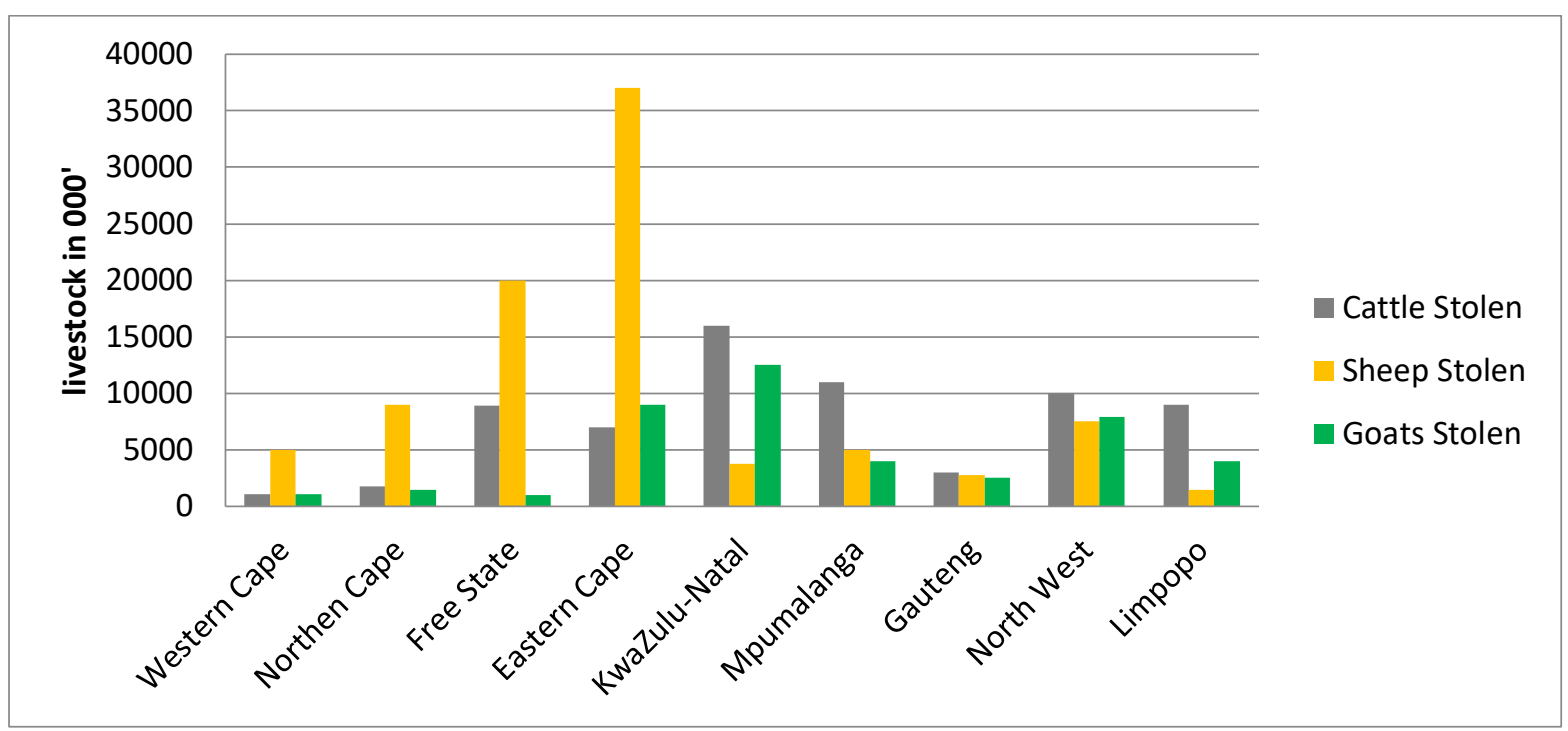

Figure 4 Number of livestock stolen per province in the financial year 2017/18 Sources: SAPS (2018) and Clack (2018)

By analysing National Livestock Theft data, Clack (2018) could show the seriousness of livestock theft crime and could estimate the livestock species theft per day in South Africa. He found that 178 cattle, 249 sheep and 115 goats are stolen per day. South African farmers are facing numerous challenges, such as frequent drought periods and high production costs that push down profit margins, and livestock theft adds to these problems (Bahta et al, 2016). Although livestock theft affects all farming systems, its consequences are most severe for smallholder livestock farming households because they keep a majority of the national livestock herd (Scholtz \& Bester, 2010). For example, about $40 \%$ of the 13.8 million national cattle, about $67 \%$ of the 6.3 million goats and around $12 \%$ of the sheep in South Africa are kept in communal farming systems (DAFF, 2010). However, because the individual communal farmers keep small herds, each unit lost could mean a loss of livelihood source.

So far, methods such as branding, tattooing and frequently counting animals have been recommended to curb stock theft (e.g. Lombard et al, 2017). Furthermore, Zwane et al. (2013) and Maluleke and Mofokeng (2016) suggested the use of forensic DNA technology. However, there are still several challenges that make it difficult to prosecute the perpetrators. Firstly, not all farmers brand and register their livestock, and this is particularly true for communal farmers (Lombard \& van Rooyen, 2017). This neglect reduces judiciary power because according to the Animal Identification Act 2002 (Act 6 of 2002), all animal owners should brand and register their animals. Secondly, few farmers report theft cases and of those who do, several do not have much evidence about the numbers and physical characteristics of the stolen animals. The perpetrators, on the other hand, operate in syndicates and often have more information about how the law operates than the farmers, particularly the smallholders, do. For example, the perpetrators may steal unbranded animals and brand them with their names. 


\section{DISCUSSION: POSSIBILITY AND LIKELIHOOD OF SMALLHOLDERS ADOPTING GPS ANIMAL TRACKING DEVICES}

To zoom in to the central argument of this study, we will now present the GPS animal tracking device and its uses. Then we will relate its functions to smallholders to discuss the likelihood of adoption. In doing so, we also look at the history of smallholders in adopting technology and identify factors that may stimulate adoption. Among these factors, we identify and discuss the role of agricultural extension as an information source.

\subsection{GPS animal tracking devices}

Animal tracking devices were initially developed for researchers to improve the accuracy of monitoring animal behaviour and were commercialised in the early 1990s (Maroto-Molina, Navarro-García, Príncipe-Aguirre, Gómez-Maqueda, Guerrero-Ginel, Garrido-Varo \& PérezMarín, 2019). Over the years, they have been improved and have contributed immensely to what is now called precision livestock farming, among the many uses (Berckmans, 2017). The GPS animal tracking devices come in different forms and shape for a variety of animal species. A commonly used form is a belt wrapped around an animal with a device that records the coordinates of a GPS map, allowing a person to identify a location when connected to a smart phone or computer (Nel, 2016). Another form, used for example in cattle, is an ear tag.

Several studies have documented how these devices work and how they are applicable (Turner, Udal, Larson \& Shearer, 2000; Clark, Johnson, Kniep, Jermann, Huttash, Wood, Johnson, McGillivan \& Titus, 2006; Trotter, Lamb, Hinch \& Guppy, 2010; Schieltz et al, 2017). For example, Schieltz et al (2017) and Maroto-Molina et al (2019) successfully showed how the animal tracking device can help researchers and producers to track cattle movement in a shared grazing environment at a relatively low cost. Maroto-Molina et al (2019) estimated a collar GPS livestock tracker, which they validated for use to cost between 100 and $150^{3}$ euros per device. Other researchers (e.g. Knight, Bailey \& Faulkner, 2018) proposed slightly higher prices for the device they had developed.

\subsection{Successful application of the GPS tracking device in commercial agriculture}

Numerous brands of the GPS animal tracking devices have been designed and tested for commercial purposes in South Africa to minimize the risk of stock theft (Nel, 2016; Scheepers, Malekian, Capeska Bogatinoska, and Stojkoska, 2017; Geldenhuys, 2020). These devices are not only cost effective - in 2016, the cost was about R3 800, they are also practical and fairly easy to use - a neck belt or ear tag GPS connected to a mobile phone or computer. With a solar battery and strong material, the GPS livestock tracking devices have a long lifespan. Where they have been used by commercial farmers, particularly FarmRanger (commercial brand), review reports show impressive results (Booysen, 2019).

\footnotetext{
${ }^{3}$ This cost translates to between R1 767 and R2 651 based on the exchange rate on 08 March 2020.
} 


\subsection{How can the GPS animal tracking devices be of use to smallholders?}

Farm animal behavioural studies have shown that a given herd of farm animal species usually consists of a leader and followers (Sato, 1982; Escós, Alados \& Boza, 1993). Therefore, farmers can use one or two devices for the whole herd if they can correctly identify the leadership, as described in the cited studies. One device per 20 animals is the recommended ratio (Nel, 2016). Using a tracking device would also help the livestock herders working in farm households because they tend to follow the animals the whole day. Lastly, recent improvements make these devices usable even in remote areas, and they use solar power (Maroto-Molina et al, 2019). Nel (2016) even suggested using dummy collars to divert attention from the functional collar to confuse thieves.

Although the main discussion is on using animal tracking devices to reduce stock theft, these devices can also help communal farmers or smallholders sharing grazing land (as is the case with South African smallholders) to monitor animal movements. This monitoring can in turn reduce the number of animals lost due to theft and animals wandering off to the national roads. Regarding the latter, Verster and Fourie (2018) reported that stray animals are one of the causes of road accidents on South African roads. Furthermore, not only animals but also human lives are lost due to collision with animals.

Smallholders with animal herders can monitor and manage livestock herders because they can track where their animals graze (Goni, Skenjana \& Nyangiwe, 2018). This is an advantage and a time-maximising tool, because some of the emerging farmers have other full-time jobs (Nieuwoudt, 2000) and therefore have little time to monitor their livestock herders. However, to better estimate the likelihood of adoption of GPS animal tracking devices, we next review how South African smallholders have reacted to previous agricultural innovations and identify factors that should be considered to stimulate adoption of this technology.

\subsection{Smallholders and technology adoption}

Smallholders are generally perceived as lagging behind in technology adoption (Kirsten \& van Zyl, 1998; Takahashi, Muraoka \& Otsuka, 2020). The lack of use of modern technology has widely been cited and attributed to the poverty of smallholders (van Marle-Köster \& Visser, 2018). Muzari, Gatsi and Muvhunzi (2012) identified seven factors influencing technology adoption among smallholder farmers in sub-Saharan Africa. These factors include assets, income, institutions, vulnerability, awareness, labour and innovativeness of smallholder farmers.

There are a variety of new technologies and innovation in agriculture, and they include farm machinery and the use of new and high-yielding crop varieties and commercial livestock breeds, among others. In the case of crop seed varieties, Gouse (2012) found that when smallholders see the impact of a new farming technology, they can adopt it. However, in the 
case of GPS animal tracking devices, there are still the open questions whether smallholders are aware of this technology and, secondly, whether they can adopt it.

Numerous factors will influence the decision whether to adopt GPS animal tracking technology. Firstly, do livestock smallholders have enough information about these devices and do they know how the devices work? This remains an open question (refer to the next section). Secondly, is stock theft a major challenge to them? It certainly is one in the Eastern Cape, Free State and KwaZulu-Natal (as shown in Figure 4). Thirdly, do they already have cell phones, particularly smart phones, and do they have connection to the internet where they live (Aker, 2011)? In this regard, the 2018 General Household Survey, which also includes nonfarming households, showed that more than $95 \%$ of households in South Africa have mobile phones (Statistics South Africa, 2018). Connor (2020) found that smart phone users among rural households tend to be younger and employed. Lastly, do they have a reasonable income and do the marginal benefits of purchasing a GPS animal tracking device exceed the marginal costs? In the previous section, we have shown the income groups of commercially oriented smallholders, whose incomes are slightly higher than those of subsistence smallholders, who mostly depend on social grants. In this regard, Chipfupa and Wale (2020) showed that smallholders with more psychological capital and resilience earn more income (R33 707 and R36 147, respectively) than those with limited interest in farming (R26 043). Furthermore, the cost-benefit calculation will be determined by the farming orientation and the contribution of livestock to the household income. For example, the commercially oriented small-scale farming households presented in Figure 3 might benefit from investing in tracking devices to reduce stock theft. The farming orientation is partly determined by the reasons for engaging in agriculture (shown in Figure 2). Those farming to attain a main and extra income source will be most likely to adopt the GPS tracking devices because livestock theft threatens their livelihood. Such agricultural households belong in the category of emerging or potential emerging smallholders. Subsistence smallholders, who mainly engage in farming for an additional food or income source, are unlikely to adopt the GPS livestock trackers. In addition, subsistence farmers own very small herds, in contrast to emerging farmers (Zantsi \& Bester, 2019a).

\subsection{Role of extension in farmer development}

Agricultural extension has an important role in farmer development that was cited and outlined in numerous studies (Davis, 2008; Davis \& Terblanché, 2016; Lyne, Jonas \& Ortmann, 2018). It is particularly important in the smallholder farming systems. One of the functions of agricultural extension and education is that of disseminating information and technology to farmers and reporting the responses to researchers to improve the service (Worth, 2006). The important goal in this respect is to help farmers use the existing information to make better decisions and achieve their own goals (Anderson \& Feder, 2004; Zantsi \& Bester, 2019b). Lyne et al (2018) quantified the impact of agricultural extension on smallholder farmers and found impressive benefits such as increased farm and net incomes. 
In the smallholder and communal farming system, farming households are poor and have low education levels, which are factors that make them especially reliant on public agricultural extension for advice and information on new, advanced farming technologies (Lukhalo, 2017). The ultimate goal of providing agricultural extension services is to improve the livelihoods of farmers. South African smallholders heavily rely on public agricultural extension (Zwane \& Groenewald, 2014). However, the question is whether agricultural extension plays this role in a meaningful manner in South Africa. The answer among researchers in sub-Saharan Africa (Takahashi et al, 2020) and South Africa has been 'no', due to numerous factors (see for example Worth, 2008 for details) ranging from a low ratio of extensionists to farmers (Aliber, Gwala, Yusuf, Rahim, Mushunje, Arwari, Makhunga \& Shiliga, 2017; Lukhalo, 2017) to incompetent extensionists (Zwane \& Groenewald, 2014), among others.

An extensive literature survey in sub-Saharan Africa showed that profitable technological advance does not spread in the region because of weak agricultural extension (Takahashi et al, 2020). Furthermore, markets for such devices in rural areas where a majority of smallholders live and farm (Pienaar \& von Fintel, 2014) may be rather scarce or non-existent (Kirsten \& van Zyl, 1998). Therefore, there is a fair chance that smallholders might not adopt the GPS animal tracking devices merely because they are not aware of their existence or do not know how to use them. Thus, the role of agricultural extension personnel would be to inform smallholders about GPS animal tracking devices, to explain where and how such tracking is possible, and to lay out appropriate possibilities of adopting these devices. However, it should be left to the farmers to decide whether this technology would be worth adopting.

\section{CONCLUSIONS AND RECOMMENDATIONS}

This review has endeavoured to illuminate a discussion as to whether GPS animal tracking devices can be adopted by smallholder livestock farmers in South Africa. We provided a review of South African farming systems with emphasis on smallholder livestock farming systems and discussed the challenges faced by the smallholders. The challenge of stock theft and its acuteness was shown by statistics and supporting literature. Based on the results, this article revealed the possibilities and likelihood of adoption of GPS livestock tracking devices by different smallholder farming typologies. This discussion was linked to the benefits, application and cost implications as well as the role of agricultural extension in disseminating adequate information on the use of GPS animal tracking devices.

Due to the agricultural landscape in South Africa, livestock is the dominant form of agricultural production in both commercial and smallholder farming systems. Smallholders own a large share of the South African livestock herd. Subsistence smallholder livestock farmers are relatively poor, own very small herds, and are less inclined to sell animals than emerging farmers are. The latter are likely to be more educated and relatively young with better access to information, making them more relevant users and more likely adopters of new technology. 
Among the many challenges faced by livestock farmers, stock theft is a big problem. Clack (2018) found that 178 cattle, 249 sheep and 115 goats are stolen per day. Sheep and goats are the most prone to theft. It is not yet clear how much the severity of the problem varies between commercial and smallholder farming systems, in terms of both numbers of lost animals and loss of livelihood. Future studies are needed in this direction.

Agricultural extensionists have an important role in making the farmers they serve aware of innovation and helping them make better and informed decisions to improve their livelihoods (Anderson \& Feder, 2004). However, based on the available evidence, it is doubtful whether South African agricultural extension may have best performed this role (Worth, 2008; Zwane \& Groenewald, 2014). It is recommended to make smallholders aware of GPS animal tracking devices, but the decision to adopt or not should be left to them.

Based on the review of the consulted literature and our discussion, it seems reasonable to conclude that adoption of GPS animal tracking devices will depend on a) the awareness about the devices and knowledge of how they work, b) the acuteness of stock theft for a farmer, and how livestock contributes to his or her livelihood, and c) the income level, access to mobile phones and risk behaviour of farmers. Because this study depended on secondary data and a review of the literature, we do not have sufficient empirical evidence for our conclusions. Further research is needed to determine the level of awareness of South African farmers about GPS animal tracking devices and whether smallholders would be willing to adopt this technology.

\section{ACKNOWLEDGEMENTS}

The financial assistance from the National Research Foundation (NRF), the Swiss National Science Foundation (SNSF) and the National Agricultural Marketing Council towards this research is hereby acknowledged. Opinions expressed, and conclusions arrived at, are those of the authors and are not necessarily to be attributed to the aforementioned funding bodies.

\section{REFERENCES}

AKER, J.C. 2011. Dial "A" for agriculture: A review of information and communication technologies for agricultural extension in developing countries. Agric. Econ., 42(6):631-647

ALIBER, M. \& HART, T.G.B. 2009. Should subsistence farming be supported as a strategy to address rural food insecurity? Agrekon, 48(4):434-458

ALIBER, M., GWALA, L., YUSUF, F., RAHIM, A., MUSHUNJE, A., ARWARI, M., MAKHUNGA, Z. \& SHILIGA, Z. 2017. Government and small-scale agriculture: Understanding the successes and failures in respect of learning, planning and implementation. Research report. Available from: http://psppdknowledgerepository.org/component/jdownloads/download/287- 
government-and-small-scale-agriculture-understanding-the-successes-and-failures-inrespect-of-learning-planning-and-implementation. Accessed: 16 February 2020

ALIBER, M. 2019. How can we promote a range of livelihood opportunities through land redistribution? Working Paper No. 58. Programme for Land and Agrarian Studies, University of the Western Cape, South Africa

ANDERSON, J. \& FEDER, G. 2004. Agricultural extension: Good intentions and hard realities. World Bank Res. Obser., 19(1):41-60

BAHTA, Y.T., JORDAAN, A. \& MUYAMBO, F. 2016. Communal farmers' perception of drought in South Africa: Policy implication for drought risk reduction. Int. J. Disast. Risk Red., 20:39-50

BAIYEGUNHI, L.J.S., MAJOKWENI, Z.P. \& FERRER, S.R.D. 2019. Impact of outsourced agricultural extension program on smallholder farmers' net farm income in Msinga, KwaZulu-Natal, South Africa. Technol. Soc., 57:1-7

BERCKMANS, D. 2017. General introduction to precision livestock farming. Anim. Front., 7(1):6-11

BOOYSEN, J. 2019. Local app helps farmers protect their livestock. IOL. June 16. Available at www.iol.co.za/business-report/economy/local-app-helps-farmers-protect-theirlivestock-26131747

CHIPFUPA, U. \& WALE, E. 2020. Linking earned income, psychological capital and social grant dependency: Empirical evidence from rural KwaZulu-Natal (South Africa) and implications for policy. J. Econ. Struct., 9:22

CLACK, W.J. 2015. The role of social media in livestock theft: A case study. Acta Criminol.: South. Afr. J. Criminol., 28(1):112-127

CLACK, W. 2018. Livestock theft: A global and South African perspective. Stock theft report presented at the National Red Meat Producers Congress, 11-12 September, Pretoria, South Africa

CLARK, P.E., JOHNSON, D.E., KNIEP, M.A., JERMANN, P., HUTTASH, B., WOOD, A., JOHNSON, M., MCGILLIVAN, C. \& TITUS, K. 2006. An advanced, low-cost, GPSbased animal tracking system. Rangeland Ecol. Manage., 59(3):334-340

CONNOR, T. 2020. Rural transformation, network society and the information age: The case of Nkonkobe District Municipality in the Eastern Cape. Jnl. Transd. Res in Sou. Afr., 16 (1): a825. https://doi.org/10.4102/td.v16i1.825

CONRADIE, B.I. 2013. Urban agriculture's enterprise potential: Exploring vegetable box schemes in Cape Town. Agrekon, 52(sup1):64-86 
COUSINS, B. 2015. 'Through a glass, darkly': Towards agrarian transformation in South Africa. In Cousins, B. \& Walker, C. (Eds.), Land divided, land restored. Land reform in South Africa for the 21st century. Jacana, Auckland Park, South Africa

DANIELS, R.C., PARTRIDGE, A., KEKANA, D. \& MUSUNDWA, S. 2013. Rural livelihoods in South Africa. SALDRU Working Paper No. 122, NIDS Discussion Paper 2013/4. University of Cape Town, South Africa

DAVIS, K. 2008. Extension in sub-Saharan Africa: Overview and assessment of past and current models, and future prospects. J. Int. Agric. Ext. Edu., 15(3):15-28

DAVIS, K.E. \& TERBLANCHÉ, S.E. 2016. Challenges facing the agricultural extension landscape in South Africa. S. Afr. J. Agric. Ext., 44(2):231-247

DEPARTMENT OF AGRICULTURE, FORESTRY AND FISHERIES. 2010. Livestock numbers: communal and commercial- November 2010. Pretoria, South Africa

DEPARTMENT OF AGRICULTURE, FORESTRY AND FISHERIES (DAFF). 2017. Abstract of agricultural statistics. Private Bag X144. Directorate: Knowledge and Information Management, Pretoria, South Africa

DEPARTMENT OF AGRICULTURE, FORESTRY AND FISHERIES (DAFF). 2019. Abstract of agricultural statistics. Private Bag X144. Directorate: Knowledge and Information Management, Pretoria, South Africa

ESCÓS, J., ALADOS, C.L. \& BOZA, J. 1993. Leadership in a domestic goat herd. Appl. Anim. Behav. Sci., 38(1):41-47

FIELKE, S., TAYLOR, B. \& JAKKU, E. 2020. Digitalisation of agricultural knowledge and advice networks: A state-of-the art review. Agric. Syst., 180:102763

GELDENHUYS, K. 2020. Stock theft : a costly, cruel crime - research. Servamus Communitybased Safety and Security Magazine, 113 (3):14-20

GONI, S., SKENJANA, A. \& NYANGIWE, N., 2018. The status of livestock production in communal farming areas of the Eastern Cape: A case of Majali Community, Peelton. Appl. Anim. Husb. Rural Dev., 11:34-40

GOUSE, M. 2012. GM maize as a subsistence crop: The South African smallholder experience. AgBioForum, 15(2):163-174

GWIRIRI, L.C., BENNETT, J., MAPIYE, C. \& BURBI, S. 2019. Unpacking the emergent farmer concept in agrarian reform: Evidence from livestock farmers in South Africa. Dev. Change, 50(6):1664-1686

HULL, E. 2014. The social dynamics of labour shortage in South African small-scale agriculture. World Dev., 59(1):451-460 
KIRSTEN, J.F. \& VAN ZYL, J. 1998. Defining small-scale farmers in the South African context. Agrekon, 37(4):551-562

KNIGHT, C.W., BAILEY, D.W. \& FAULKNER, D. 2018. Low-cost Global Positioning System tracking collars for use on cattle. Rangeland Ecol. Manage., 71:506-508

KUNENE-NGUBANE, P., CHIMONYO, M. \& KOLANISI, K. 2018. Possibility of organic beef production on South African communal farms. S. Afr. J. Agric. Ext., 46(1):1-13

LIEBENBERG, F. 2015. Agricultural advisory services in South Africa. Discussion Paper, 17 July. University of Pretoria, South Africa. Available from: http://www.up.ac.za/media/shared/108/2015\%20Working\%20papers/agric_advisory_ services.zp64017.pdf. Accessed: 20 October 2019

LOMBARD, W.A., VAN NIEKERK, H.N. \& MARÉ, F.A. 2017. Assessing the economic impact of livestock theft in the Eastern Cape Province of South Africa. 21st International Farm Management Congress, John McIntyre Conference Centre, Edinburgh, Scotland, United Kingdom

LOMBARD, W.A. \& VAN ROOYEN, F.M. 2017. Stock theft trends and the role of unmarked livestock. Stockfarm, 7(4):8-9

LUKHALO, T. 2017. An expenditure review of the agricultural extension system in South Africa. Master's Thesis. University of Pretoria, South Africa

LYNE, M.C., JONAS, N \& ORTMANN, G.F. 2018. A quantitative assessment of an outsourced agricultural extension service in the Umzimkhulu District of KwaZuluNatal, South Africa. Jnl. of Agric. Educ. Ext., 24:1, 51-64

MALULEKE, W., OBIOHA, E.E. \& MOFOKENG, J.T. 2014. Assessment of policing and prevention strategies of stock theft in South Africa: A case study of Giyani Policing Area, Republic of South Africa. Mediterr. J. Soc. Sci., 5(23):2148-2157

MALULEKE, W. \& MOFOKENG, J.T. 2016. The use of deoxyribonucleic acid in combating stock theft: Experiences and recommendations of South African Police Service KwaZulu-Natal selected stock theft units. Int. J. Bus. Manage. Stud., 8(1):50-69

MALULEKE, W., MOKWENA, R.J. \& MOTSEPA, L.L. 2016. Rural farmers' perspectives on stock theft: Police crime statistics. S. Afr. J. Agric. Ext., 44(2):256-274

MAROTO-MOLINA, F., NAVARRO-GARCÍA, J., PRÍNCIPE-AGUIRRE, K., GÓMEZMAQUEDA, G., GUERRERO-GINEL, J.E., GARRIDO-VARO, A. \& PÉREZMARÍN, D.C. 2019. A low-cost IoT-based system to monitor the location of a whole herd. Sensors, 19:2298

MTHI, S., SKENJANA, A. \& FAYEMI, P.O. 2017. Characteristics of small-scale sheep production systems in some communal areas of the Eastern Cape Province, South Africa. Int. J. Livest. Prod., 8(12):199-206 
MUZARI, W., GATSI, W. \& MUVHUNZI, S. 2012. The impacts of technology adoption on smallholder agricultural productivity in sub-Saharan Africa: A review. J. Sustain. Dev., 5(8):69-77

NEL, C. 2016. Keep track of your cattle 24/7. Farmers' Weekly, 15 March 2016

NIEUWOUDT, W.L. 2000. An economic evaluation of a crop insurance programme for smallscale commercial farmers in South Africa. Agrekon, 39(3):269-291

NKWARI, P.K.M., RIMER, S. \& PAUL, B.S. 2014. Cattle monitoring system using wireless sensor network in order to prevent cattle rustling. In Cunningham, P. \& Cunningham, M. (Eds.), IST-Africa 2014 Conference Proceedings. IIMC International Information Management Corporation, Ireland

NTSEBEZA, L. 2002. Cattle production in Xhalanga District. In: Ainslie, A. (Ed.), Cattle ownership and production in the communal areas of the Eastern Cape, South Africa. Research Report No. 10. Programme for Land and Agrarian Studies, University of the Western Cape, South Africa

OKUNLOLA, A., NGUBANE, M., COUSINS, B. \& DU TOIT, A. 2016. Challenging the stereotypes: Small-scale black farmers and private sector support programmes in South Africa. Research Report No. 53. Institute for Poverty, Land and Agrarian Studies, University of the Western Cape, South Africa

PIENAAR, P.L. 2013. Typology of smallholder farming in South Africa's former homelands: Towards an appropriate classification system. Unpublished Master's Thesis. Stellenbosch University, South Africa

PIENAAR, L. \& VON FINTEL, D. 2014. Hunger in the former apartheid homelands: Determinants of convergence one century after the 1913 Land Act. Agrekon, 53(4):3867

RAIDIMI, E.N. 2014. The roles and activities of women in the six selected agricultural projects in Thulamela Local Municipality of Vhembe District Municipality in the Limpopo Province. S. Afr. J. Agric. Ext., 42(2):10-23

SATO, S. 1982. Leadership during actual grazing in a small herd of cattle. Appl. Anim. Ethol., 8(1-2):53-65

SCHIELTZ, J.M., OKANGA, S., ALLAN, B.F. \& RUBENSTEIN, D.I. 2017. GPS tracking cattle as a monitoring tool for conservation and management. Afr. J. Range For. Sci., 34(3):173-177

SCHEEPERS, G., MALEKIAN, R., BOGATINOSKA, D.C. AND STOJKOSKA, B.R. 2017. A low-power cost-effective flexible solar panel powered device for wireless livestock tracking. 25th Telecommunications forum, Serbia, Belgrade, November 21-22 
SCHOLTZ, M.M. \& BESTER, J. 2010. Off-take and production statistics in the different South African cattle sectors: Results of a structured survey. Appl. Anim. Husb. Rural Dev., $3: 19-23$

SNYDER, H. 2019. Literature review as a research methodology: An overview and guidelines. J. Bus. Res., 104:333-339

STATISTICS SOUTH AFRICA. 2016. General Household Survey, 2016. Available from: http://www.statssa.gov.za/?p=9922

STATISTICS SOUTH AFRICA. 2018. General Household Survey, 2018 [dataset]. Version 1. Pretoria, South Africa

STATISTICS SOUTH AFRICA (STATSSA). 2020. Census of commercial agriculture, 2017-Financial and production statistics. Report No. 11-02-01 (2017). Pretoria

TAKAHASHI, K., MURAOKA, R. \& OTSUKA, K. 2020. Technology adoption, impact, and extension in developing countries' agriculture: A review of the recent literature. Agric. Econ., 51:31-45

TROTTER, M.G., LAMB, D.W., HINCH, G.N. \& GUPPY, C.N. 2010. GNSS tracking of livestock: Towards variable fertilizer strategies for the grazing industry. Paper presented at the 10th International Conference on Precision Agriculture, 18-21 July, Denver, Colorado, USA

TURNER, L.W., UDAL, M.C., LARSON, B.T. \& SHEARER, S.A. 2000. Monitoring cattle behavior and pasture use with GPS and GIS. Can. J. Anim. Sci., 80:405-413

VAN MARLE-KÖSTER, E. \& VISSER, C. 2018. Genetic improvement in South African livestock: Can genomics bridge the gap between the developed and developing sectors? Front. Genet. 9:331

VAN NIEKERK, J.A, MAHLOBOGOANE, M. \& TIRIVANHU, P. 2015. The transfer of intergenerational family knowledge for sustainable commercial farming in Mpumalanga Province of South Africa: Lessons for extension. S. Afr. J. Agric. Ext., 43(1):66-77

VERSTER, T. \& FOURIE, E. 2018. The good, the bad and the ugly of South African fatal road accidents. S. Afr. J. Sci., 114(7-8):63-69

VETTER, S. 2013. Development and sustainable management of rangeland commons Aligning policy with the realities of South Africa's rural landscape. Afr. J. Range For. Sci., 30(1-2):1-9

VINK, N. \& VAN ROOYEN, J.C. 2009. The economic performance of agriculture in South Africa since 1994: Implications for food security. Development Planning Working Paper Series No. 17. Development Bank of Southern Africa, Midrand, South Africa 
WORTH, S.H. 2006. Agriflection: A learning model for agricultural extension in South Africa. J. Agric. Edu. Ext., 12(3):179-193

WORTH, S.H., 2008. An assessment of the appropriateness of agricultural extension education in South Africa. PhD Thesis. University of KwaZulu-Natal, South Africa

ZANTSI, S. \& BESTER, B. 2019a. Revisiting the benefits of animal traction to subsistence smallholder farmers: A case study of Ndabakazi villages in Butterworth, Eastern Cape Province of South Africa. S. Afr. J. Agric. Ext., 47(3):1-13

ZANTSI, S. \& BESTER, B. 2019b. Change in farming households' livelihood strategies in Ndabakazi villages, Eastern Cape: What are the implications to agricultural extension services? S. Afr. J. Agric. Ext., 47(4):120-134

ZANTSI, S., GREYLING, J.C. \& VINK, N. 2019. Towards a common understanding of 'emerging farmer' in a South African context using data from a survey of three district municipalities in the Eastern Cape Province. S. Afr. J. Agric. Ext., 47(2):81-93

ZANTSI, S. \& MACK, G. 2019. Degree and determinants of smallholder commercialisation in rural former homeland areas of South Africa. International Association of Agricultural Economist Symposium on 'Small-holder farms in market integration Lessons and experiences from South and East Asia', 11-13 November, Nanjing, China

ZANTSI, S. \& MACK, G. 2020. Towards a viable farm size - Determining a viable farm household income for emerging farmers in South Africa's Land Redistribution Programme: An income aspiration. Manuscript resubmitted to Agrekon

ZWANE, E.M. \& GROENEWALD, I.B. 2014. Critical factors influencing performance of extensionists in Limpopo Department of Agriculture in South Africa. S. Afr. J. Agric. Ext., 42(1):49-61

ZWANE A.A., VAN MARLE-KÖSTER, E., GREYLING B.J. \& MAPHOLI, N. 2013. A review: Forensic DNA technology to meet the stock theft challenges in South Africa. Appl. Anim. Husb. Rural Dev., 6: 36-47 